\title{
NATUREZA DOS DEUSES E DIVINDADE DA NATUREZA: REFLEXÕES SOBRE A RECEPÇÃO ANTIGA E MODERNA DO ANTROPOMORFISMO DIVINO GREGO
}

\author{
Antonio Orlando Dourado Lopes* \\ aoodlopes@gmail.com
}

"L'homme est un dieu qui se méconnaît."

Francis Ponge, Notes premières de «l'homme».

RESUMO $A$ dificuldade em admitir-se o antropomorfismo dos deuses aparece na Grécia a partir da época arcaica, com os primeiros textos em prosa dos pensadores pré-socráticos. Neste estudo definirei as principais características dessa reflexão crítica sobre os limites do antropomorfismo, bem como a recusa dos intérpretes modernos em aceitar o antropomorfismo grego como uma experiência religiosa autêntica. Alguns fragmentos de Heráclito de Éfeso serão citados como exemplo da sabedoria dos jônios na época arcaica.

Palavras-chave religião grega, antropomorfismo, poemas homéricos, exegese homérica.

ABSTRACT The difficulty in admitting divine anthropomorphism appears in Greece from the archaic epoch onwards with the first prose texts

* Professor da Faculdade de Letras/Letras Clássicas da UFMG. Recebido em 5/4/2010 e aprovado em $4 / 5 / 2010$.

KRITERION, Belo Horizonte, nº 122, Dez./2010, p. 377-397. 
of the pre-Socratic thinkers. In this study I will define the main characteristics of this critical reflexion about the limits of anthropomorphism, as well as the modern scholars' refusal to accept it as an authentic religious experience. Some fragments of Heraclitus of Ephesus will be cited as an example of the Ionian wisdom of the archaic epoch.

Keywords Greek religion, anthropomorphism, Homeric poems, Homeric scholarship

Já há algum tempo acredita-se que o antropomorfismo é uma característica essencial dos deuses gregos, documentável, embora fragmentariamente, desde o período micênico. Ele tem nos poemas homéricos um de seus testemunhos mais vigorosos se não, simplesmente, o mais vigoroso. Estes, por sua vez, constituem tanto uma verdadeira experiência da piedade grega quanto um momento a mais em sua longa evolução. A liberdade poética que parecem exercer não torna infiel sua representação dos deuses, mas obedece à expectativa tipicamente grega de atribuir à poesia uma função ativa na experiência do culto. ${ }^{1}$

O período arcaico conhece o antropomorfismo como a tensão entre o grande desenvolvimento das suas possibilidades de representação iconográfica e, de outro lado, a crítica contundente dos primeiros textos em prosa dos pensadores jônicos. A longa e complexa elaboração da noção de 'physis' cria as exigências de uma nova racionalidade, que gera sucessivas hipóteses sobre a natureza dos deuses e do divino. Em vez de apresentar o mundo divino, como as narrativas mitológicas, a nova reflexão procura dar um sentido ao divino.

Para valorizar a dimensão religiosa dessa nova reflexão, exporei a seguir (1) alguns aspectos teóricos do distanciamento dos primeiros pensadores em relação à crença no antropomorfismo divino no período arcaico. Precedendo a consolidação da noção de physis, esse distanciamento parece ter deixado espaço para a visão materialista e naturalista da realidade que então se elaborava. Na segunda parte do estudo (2), mostrarei como motivos diversos

1 Fiz uma breve exposição dessas questões em DOURADO-LOPES, A. O. "A força e o antropomorfismo dos deuses gregos. Considerações sobre a religião dos poemas homéricos". Aletria, v. 20, n. 2: "Os clássicos", julho-dezembro de 2009, p. 11-27. 
levaram à incompreensão e ao repúdio do antropomorfismo divino também por parte de estudiosos modernos da religião grega.

\section{Os primeiros intérpretes de Homero no período arcaico}

Nos poemas homéricos a natureza está presente nos fenômenos com que o poeta compara os grandes acontecimentos. Lembremo-nos de como diversas cenas de batalha da Ilíada relacionam a guerra com uma tempestade e evocam a força devastadora da natureza e do deserto. ${ }^{2} \mathrm{G}$. Vlastos chegou a perguntar: «o que há de mais típico da religião grega do que a personificação de ventos, fontes, rios, terra, estações, graças, amor, vitória, justiça, paz, etc., cuja vitalidade religiosa é atestada no culto?» ${ }^{3}$ Esse olhar atento e admirativo para a natureza e sua tradução vigorosa na experiência do divino reaparece nas novas especulações dos pensadores pré-socráticos. W. Jæger fala de uma «marca unitária da especulação dos pré-socráticos sobre o divino»:

"A questão sobre a origem de todas as coisas era tão extensa, ela se projetava tão além de todas as crenças e opiniões, que sua resposta compreendia também, necessariamente, um novo exame da verdadeira essência da força superior que o mito venerava como 'deuses'. Na causa primordial do devir, que tudo produz, pouco importa como ela se definia de mais perto, o pensamento filosófico encontrou rapidamente retida a encarnação de todo o divino.» ${ }^{4}$

Na medida em que se pode dizer que a religião grega tinha nela mesma a predisposição a uma transformação contínua e, por outro lado, na medida em que era orientada para a natureza e a experiência humana, as concepções

2 Veja-se, por exemplo, a batalha pelos despojos de Pátroclo: aqueus e troianos lutam "como o fogo" (démas pyrós) e ofuscam o presente ao ponto de impedi-los de saber-se se o sol e a lua ainda existem (llíada, XVII, 366-369); contra os aqueus "desdobra-se um combate feroz, semelhante ao incêndio" (ágrios eúte pyr); os dois Ajax retêm os troianos como um rio (736-753); os guerreiros continuam a combater "semelhantes ao fogo flamejante" (démas pyrós aithoménoio, XVIII, 1). Cf. MUGLER, C. Les origines de la science grecque chez Homère. L'homme et l'univers physique. Paris: Klincksieck, 1963, p. 3 (a respeito do ardor guerreiro): "Essas forças humanas e seus efeitos são frequentemente comparadas na llíada e na Odisseia com as forças da natureza e com seus efeitos. [...] Mas todas essas comparações, muito numerosas, foram precedidas, na representação dos gregos, por comparações em sentido inverso, nas quais as forças da natureza foram assimiladas às forças do homem e dos seres vivos em geral. A epopeia conserva numerosos traços desse antropomorfismo ancestral."

3 VLASTOS, G. "Theology and philosophy in early greek thought". In: Studies in greek philosophy. Volume I: the presocratics. Edited by D. W. Graham. Princeton (New Jersey): Princeton University Press, 1993, p. 3-31; p. 5 para a citação. A pergunta é formulada em meio a uma crítica à má compreensão de J. Burnet sobre as personificações em Hesíodo.

4 J/EGER, W. Die Theologie der frühen Griechischen Denker. Stuttgart: Kohlhammer, 1964, capítulo 10: Die Theorien über das Wesen und Ursprung der Religion, p. 196-216; p. 196-197 para a citação. Vejase também BURKERT, W. Griechische Religion der archaischen und klassischen Epoche. Stuttgart: Kohlhammer, 1977, p. 199. 
religiosas dos pensadores pré-socráticos podem também ser consideradas um desenvolvimento da religião que elas pretendem examinar e explicar. As novas explicações uniam o conhecimento à veneração dos deuses ${ }^{5}$.

A relação dessas novas especulações com a religião tradicional ia da simples recusa a uma espécie de reinterpretação crítica. ${ }^{6}$ Todavia, a transmissão fragmentária dos textos não nos permite conhecer com exatidão as etapas ou as motivações precisas que justificaram essas diversas perspectivas. Supôs-se frequentemente que a interpretação alegórica dos poemas homéricos teria sido introduzida por Teágenes de Régio ao final do século VI a. C. Tratar-se-ia, inicialmente, de responder às críticas da representação homérica dos deuses apresentadas por Xenófanes de Colofão e possivelmente também por outros. ${ }^{7}$ Essa hipótese se baseia num escólio ao canto XX da Ilíada, cuja origem e data não são, entretanto, facilmente determináveis. Não podemos nem mesmo saber se Teágenes era um rapsodo ou um gramático. ${ }^{8}$ Porém, estudos recentes

5 NILSSON. Geschichte der griechischen Religion. I. Band: die Religion Griechenlands bis auf die griechische Weltherrschaft. Munique: C. H. Beck'sche, 1955 ( $3^{\mathrm{a}}$ ed., 1967), p. 80: "Os gregos eram racionalistas. É, de fato, surpreendente o pouco que eles acreditaram na força eficaz da imagem e do nome por oposição a muitos outros povos." Veja-se RUDHART, J. "Considérations sur le polythéisme", Revue de Théologie et de Philosophie, p. 356: "O pensamento pagão não separa o divino do mundo; é no homem, na história e no mundo que ele apreende a ação divina, que ele decodifica seus sinais mais evidentes [...]." A despeito de suas qualidades, veja-se abaixo, nota 43 , minha crítica às conclusões finais desse texto. Para J/EGER, W. Die Theologie der frühen Griechischen Denker, p. 197 e 199, "[...] toda experiência grega dos deuses é dirigida à realidade e orientada para ela. No nível do pensamento natural-filosófico iniciante, essa realidade é apreendida com foças totalmente novas e em formas totalmente novas. [...] Um pensamento que deduz tudo o que existe da natureza deveria necessariamente conseguir considerar, a partir de sua ordem regular, as crenças nos deuses como um produto da natureza humana e das suas trocas com o mundo circundante, e tudo isso mesmo como algo de natural." Na mesma direção vão as observações de COULOUBARITSIS, L. Aux origines de la pensée européenne. De la pensée archaïque au néoplatonisme. Bruxelles: De Boek, 1992, p. 28, que afirma que a religião grega teria «uma certa liberdade de pensamento (que as religiões orientais não parecem autorizar) que contribui ao seu modo para o advento do pensamento filosófico. Mas o elemento determinante dessa evolução do pensamento é a oposição entre mito e religião, sem dúvida mais marcada entre os gregos do que em outras culturas.»

6 J/EGER, W. Die Theologie der frühen Griechischen Denker, p. 197-199, que cita Heráclito, B 32 DK, e observa: "O pensamento geral, no qual o momento da antiga espiritualidade parecia antes desaparecer, apreende de novo o espírito na sua ideia do divino e se aproxima ainda uma vez de uma concepção mítica dos deuses, coma numa espiral de um nível mais alto". A importância da temática religiosa para os pensadores pré-socráticos também é salientada por VLASTOS, G. "Theology and philosophy in early greek thought", p. 3: "Os principais temas de todos os physiologoi [...] eram assuntos de vívido aporte religioso para seus contemporâneos." Após criticar a visão distorcida de John Burnet, para quem a palavra 'theós' não tinha sentido propriamente religioso entre os pré-socráticos, Vlastos observa a respeito destes (p. 4) que "seu objeto primário é compreender a natureza, não reformar a religião."

7 RICHARDSON, N. The lliad: a commentary. Volume VI: books XXI-XXIV. Cambridge: Cambridge University Press, p. 27, menciona Teágenes no contexto de uma "tentativa de fazer face aos ataques dos filósofos em seu próprio terreno por meio da alegoria". O mesmo ponto de vista é sustentado por DETIENNE, M. L'invention de la mythologie. Paris: Gallimard, p. 129-131, para quem as reflexões de Teágenes são "um sinal, entre outros, de que no século VI Homero ainda fica a meio-caminho entre a oralidade comum e a alfabetização restrita a uma elite que descobre as delícias do sentido escondido" (p. 131).

8 Trata-se do escólio B a llíada, XX, 67, como nos informa CALIFF, D. J. "Metrodorus of Lampsacus and allegory: an extreme case?". Arethusa, 36, 2003, p. 26-27. A dúvida é salientada por ROCCA-SERRA, G. Naissance de l'exégèse allégorique et naissance de la raison. In: MATTÉl, J. F., org. La naissance de la 
mostram que outros autores já haviam proposto uma interpretação alegórica antes dos primeiros críticos dos poemas homéricos, o que dissocia as duas abordagens ao menos em suas respectivas intenções iniciais. Sabe-se que contemporâneos de Xenófanes já interpretavam certas passagens dos poemas homéricos segundo um 'sentido subjacente' (hypónoia), mas isso não prova necessariamente a existência de uma interpretação alegórica remetendo a uma compreensão impessoal da physis. ${ }^{9}$

Outras fontes parecem indicar que Ferécides de Siros, cujas datas também são incertas, foi o primeiro autor a propor uma compreensão dos deuses como 'forças cósmicas'. ${ }^{10}$ Metrodoro de Lâmpsaco se inscreveria na mesma tradição que Ferécides e teria estendido aos heróis da epopeia a interpretação alegórica originalmente aplicada aos deuses. ${ }^{11}$ Suas interpretações chegaram até nós pelos comentários críticos de Filodemo e de Taciano, os quais, no entanto, não são muito precisos. ${ }^{12}$ Como quer que seja, a referência irônica a

raison en Grèce. Actes du Congrès de Nice (mai, 1987). Paris: Presses Universitaires de France, 1990, p. 77-82. Uma parte do mesmo escólio está traduzida na p. 78 do artigo. O autor observa também, $p$. 77 , que, segundo H. Schräder, é possível que esse escólio seja um trecho das Questões homéricas de Porfírio, uma possibilidade, entretanto, difícil de se confirmar. Veja-se também RICHARDSON, N. Homeric professors in the age of the sophists. Proceedings of the Cambridge Philological Society, 201 (new series 21), 1975, p. 65-81; em particular p. 67.

9 CALIFF, D. J. "Metrodorus of Lampsacus and allegory: an extreme case?", p. 26, observa que o termo allegoría é provavelmente helenístico e que o verbo allegoreúo podia ser empregado de um modo geral como sinônimo de hermeneúo. A observação de WEST, M. "The invention of Homer", p. 378, segundo a qual Teágenes foi o primeiro a escrever sobre Homero poderia explicar a falsa atribuição a ele da origem da interpretação alegórica. Uma ocorrência posterior do termo hypónoia pode dar-nos um exemplo da desconfiança dos gregos acerca da interpretação literária: tôn dè érgon tèn hypónoian hé alétheia blápsei (Tucídides, II, 41, 4).

10 CALIFF, D. J. "Metrodorus of Lampsacus and allegory: an extreme case?", p. 26-27, e BURKERT, Mito e mitologia, p. 50-52. KENNEDY, G. A. Language and meaning in Archaic and Classical Greece. In: KENNEDY, G. A., org. The Cambridge history of litterary criticism. Vol. I: classical criticism. Cambridge: Cambridge University Press, 1989, p. 78-91; em particular p. 85-86 (“Allegorical interpretation”), situa Ferécides após Teágenes (o que é irrelevanta para minha argumentação). Para VLASTOS, G. "Theology and philosophy in early greek thought", p. 15, a importância de Ferécides consistiria em fazer Zeus perder características antropomórficas e passar a ser eterno. Vlastos lembra também (p. 21, nota 77) que Ferécides é a única exceção de um autor filosófico a ter composto uma teogonia; a influência de Anaximandro sobre ele, sustentada por Jæger - Ferécides teria assimilado "críticas filosóficas do antropomorfismo" - é uma possibilidade que precisaria ainda ser comprovada.

11 RICHARDSON, N. "Homeric professors in the age of the sophists", p. 68-69, e CALIFF, D. J. "Metrodorus of Lampsacus and allegory: an extreme case?", p. 27.

12 CALIFF, D. J. "Metrodorus of Lampsacus and allegory: an extreme case?", p. 29-30. As passagens citadas são Sobre a poesia, 2, de Filodemo (DK 61 A 4), e Discurso aos Gregos, 21, de Taciano (= DK 61 A 3). Califf insiste na diferença entre uma interpretação alegórica feita por um crítico e a atribuição por um crítico de uma composição alegórica da parte do poeta. Os excessos da interpretação de Metrodoro, denunciados por Taciano e por Filodemo, parecem indicar que o primeiro não teria distinguido os dois processos, tendo atribuído a Homero concepções nas quais ele não teria jamais pensado. Na sequência de seu estudo, $p$. 30-35, Califf tenta mostrar que, apesar de suas excentricidades, a abordagem de Metrodoro "exige um engajamento com a narrativa e o conjunto das imagens da llíada que é mais amplo e mais profundo do que as alegorias verbais isoladas de muitos outros críticos antigos, que são, todavia, mais sóbrios" ( $p$. 30). 
Metrodoro feita por Platão no Ion, 530c, - sua referência mais antiga a nos ter chegado - só tem sentido se tiver sido um autor conhecido em sua época. A interpretação dos poemas homéricos estava, portanto, no coração de um intenso debate na Atenas dos séculos V e IV a. C. ${ }^{13}$

A menção a Anaxágoras como autor das teorias sobre as quais Metrodoro se teria baseado é, sem dúvida, significativa e dá testemunho da nova relação com o texto dos poemas homéricos que passa a caracterizar a época arcaica. Diógenes Laércio afirma que Anaxágoras foi o primeiro a sustentar que os poemas homéricos dizem respeito à virtude e à justiça, numa passagem que merece a nossa atenção:

"Segundo diz Favorino, na História variada, parece que foi [scil. Anaxágoras] o primeiro a declarar que a poesia de Homero é sobre a virtude e a justiça; e Metrodoro de Lâmpsaco, que era seu conhecido, estendeu ainda mais esse argumento, sendo também ele o primeiro a estudar o poeta no tocante à sua doutrina natural. E Anaxágoras foi ainda o primeiro a publicar um livro de prosa."

(Vidas e doutrinas dos filósofos ilustres, livro II, capítulo 11, 4-10) ${ }^{14}$

Duas informações nos interessam particularmente nessa passagem. Primeiramente, o nome de Anaxágoras é aqui associado à interpretação dos poemas homéricos, mas sem que isso indique tratar-se forçosamente de uma interpretação alegórica. A se levar em conta esse testemunho, a originalidade do procedimento de Anaxágoras não consistiria em tentar compreender os poemas homéricos segundo a justiça e a virtude, mas simplesmente no esforço de compreendê-los. Independentemente do que o pensador pode encontrar na sua interpretação, Diógenes Laércio salienta o fato de que Anaxágoras procurou em Homero temas para além daqueles imediatamente pertinentes às suas narrativas. Um segundo aspecto importante da passagem é a relação entre o fato de que Anaxágoras foi o primeiro a escrever uma obra em prosa e sua interpretação dos poemas homéricos (embora haja dúvidas quanto à autenticidade e o sentido dessa parte do texto). ${ }^{15}$

13 CALIFF, D. J. “Metrodorus of Lampsacus and allegory: an extreme case?”, p. 27-28.

14 Dokeî dè prôtos, katà phesí Faborînos en Pantodapêi Historíai, tèn Homérou poíesin apophénasthai eînai perí aretês kaì dikaiosynes 'epì pleîon dè prosteînai toû lógou Metródoron tòn lampsakenón, gnórimon ónta autoû, hòn kaì prôton spoudásai toû poietoû perí tèn physikèn pragmateían. Prôtos dè Anxagóras kaì biblíon exédoke syggraphês.

15 Aceito a posição do tradutor francês da passagem citada, M. Narcy (DIÓGENES LAÉRCIO. Diogène Laërce. Vies et doctrines des philosophes illustres. Traduction par M.-O. Goulet-Cazé, R. Goulet et M. Narcy. Paris: Le Livre de Poche, 1999, ad loc.), para quem "o texto não apresenta dificuldade, se se atribui a syggraphé seu sentido corrente em jônico-ático: discurso em prosa, escrito e não recitado”. Cf. VLASTOS, G. "The physical theory of Anaxagoras." In: Studies in greek philosophy. Volume I: the presocratics. Edited by D. W. Graham. Princeton (New Jersey), 1993, p. 303-327; em particular p. 306, que compara o estilo 
Os dados históricos sobre os primeiros intérpretes de Homero são, dessa forma, imprecisos demais para permitir-nos uma conclusão consistente quanto à sua origem e finalidade. Convenceu-me, de um lado, a argumentação de G. Rocca-Serra, que alertou para a necessidade de «separar-se [...] o elo que se quer estabelecer entre o nascimento da física e a exegese homérica". Tal elo pode ter sido importante num certo momento da recepção dos poemas homéricos, mas não foi provavelmente nem a única nem a primeira motivação dos intérpretes de Homero. As evidências textuais sugerem, antes de tudo, que esses primeiros intérpretes "quiseram tornar explícitas as doutrinas realmente contidas no discurso do Poeta". ${ }^{16}$ Por outro lado, penso que a argumentação de G. Rocca-Serra deve ser levada adiante, afirmando-se que essas primeiras interpretações de Homero revelam a consolidação da descrença no antropomorfismo divino. Para K. Reinhardt, o recurso à personificação como hipótese de interpretação da religião grega teria nascido de uma analogia enganadora com o processo próprio à criação poética. ${ }^{17}$

A distinção entre as novas interpretações de Homero e as teorias sobre a physis sugere que os dois procedimentos obedeceram a intenções distintas: a exegese de Homero resulta do distanciamento ocorrido entre as práticas religiosas do período arcaico e as crenças apresentadas na Ilíada e na Odisséia. Já as teorias sobre a physis pretendem explicar uma realidade que passou a demandar explicações impessoais. Portanto, a interpretação da religião homérica não é fruto da vitória do modo de pensar racionalizante sobre as crenças antropomórficas, mas sim de uma mudança mais definitiva que teria suscitado novas concepções da relação do homem com a realidade.

A partir de então, a realidade aparenta uma autonomia jamais imaginada, deixando de lado a intervenção divina e apresentando fenômenos totalmente impessoais. ${ }^{18} \mathrm{O}$ desprestígio do antropomorfismo politeísta da tradição homérica permitiu, por assim dizer, que se diluísse a polarização pessoalidade-

de Anaxágoras com o de contemporâneos, como Xenófanes e Empédocles: "mas Anaxágoras é um escritor de prosa, não um poeta; e sua prosa é singularmente sóbria, o idioma escasso da lógica e da investigação física." No entanto, a passagem citada acima tinha sido interpretada diferentemente por RICKS, R. D., edição, tradução, introdução e notas. Diogenes Laertius. Lives of eminent philosophers, Londres / Cambridge (MA), 1959, 2 vol., ad loc.: ter-se-ia atribuído a Anaxágoras "diagramas assim como textos", ou bem, como preferem outros, Anaxágoras "teria sido o primeiro a produzir um livro escrito por ele mesmo".

16 ROCCA-SERRA, G. "Naissance de l'exégèse allégorique et naissance de la raison”, p. 82 para as duas citações.

17 Expus com mais detalhes essa questão em DOURADO-LOPES, A. O. "A força e o antropomorfismo dos deuses gregos. Considerações sobre a religião dos poemas homéricos," p. 9-15.

18 CORNFORD, F. M. Greek religious thought. Londres: J. M. Dent \& Sons, 1923, "Introduction”, p. xx-xxii; FINLEY, M. I., Grécia primitiva: idade do bronze e idade arcaica. Trad. por W. R. Vaccari. São Paulo: Martins Fontes, 1990, p. 149-150. 
impessoalidade na discussão sobre o par material-imaterial, que antecipa, ao menos em parte, o par singular-universal da filosofia clássica. Em sua busca por elementos presentes em toda a realidade, os pensadores jônicos perseguiam uma chave de interpretação para os entes. Se as crenças antropomórficas continuaram vivas no culto religioso e na poesia, não deixaram, por outro lado, de ser consideradas por esses pensadores uma parte menor e subordinada ao rigor da racionalidade que começava a impor-se (noûs, phrónesis, lógos). A concorrência entre as duas formas de pensar decorria da relação com o divino que ambas pleiteavam. ${ }^{19}$ Segundo essa perspectiva, o caráter pessoal seria não apenas uma outra forma de se considerar o singular, mas sobretudo uma forma menos precisa, ingênua demais para ser levada a sério.

\section{A desconfiança teórica do estatuto religioso do antropomorfismo divino do século XVIII até os dias de hoje}

Assim como na época arcaica, a oposição entre pessoalidade e impessoalidade não teve maior importância para a concepção moderna de racionalidade. Partindo do legado conceitual da filosofia clássica, a teoria moderna do conhecimento enfocou a polaridade singular-universal em função da oposição sujeito-objeto. A despeito de toda a diferença quanto aos pressupostos metodológicos, manteve-se a visão de que a identidade 'pessoal' dos deuses homéricos seria não apenas uma outra forma de se considerar a singularidade dos acontecimentos humanos, mas também uma forma inadequada e fantasiosa de fazê-lo.

O politeísmo grego, em particular, foi tema de um vivo debate a partir do final do século XVIII que influencia até hoje os estudos de religião. ${ }^{20}$ Nascido primeiramente entre os eruditos neo-humanistas, o debate se prolongou até o romantismo alemão. Nessa época, a crítica da religião, cultivada na França pela filosofia das Lumières e alimentada pela Aufklärung alemã, havia aberto o caminho para novas interpretações da religião. ${ }^{21}$

19 É justamente esse o aspecto em que VLASTOS, G. "Theology and philosophy in early greek thought," p. 20-22, critica a interpretação de JÆEGER, W. Die Theologie der frühen Griechischen Denker, a despeito dos méritos que também Ihe reconhece. Para G. Vlastos, a relação das novas reflexões sobre a physis com a religião é mais oblíqua do que sustentou o helenista alemão: dentre todos os pensadores da época arcaica, Pitágoras é o único realmente religioso, pois fundou de fato um culto e propôs a dualidade da realidade e a transmigração das almas; a expressão tò theîon no fragmento de Anaximandro não é dele, mas de Aristóteles, bem como não existe evidência conclusiva de que Anaximandro, Parmênides ou Anaxágoras tenham chamado seus princípios cosmogônicos de 'deus'; para Anaximandro, não é o ápeiron que é divino, mas os "mundos infinitos".

20 DETIENNE, M. L'invention de la mythologie, Paris, 1981, p. 9, nos lembra do número de autores do século XIX para os quais Israel nos teria livrado do politeísmo.

21 Andrew Lang (1844-1912) a citou as "aventuras infames e ridículas" dos deuses como uma das dificuldades para os estudos científicos da mitologia. Paul Decharme (1839-1905) sustentou a separação entre a 
Durante a primeira metada do século XIX, as referências mitológicas e religiosas apresentadas pelos poemas homéricos desempenharam um papel fundamental no debate a respeito da noção de uma 'civilização indo-europeia'. Para autores como E. Renan, A. Pictet e A.-A. Cournot, na França, e F.-M. Müller e R. F. Grau, na Alemanha, os poemas homéricos constituem um momento decisivo da civilização denominada, na época, 'ariana', e o politeísmo grego "contém em germe o advento das ciências". ${ }^{22}$ Para esses autores, a oposição entre as civilizações ditas 'ariana' e 'semita' punha em movimento a evolução da humanidade numa perspectiva providencial da história que culminava no cristianismo europeu. Como consequência da polêmica contra a Igreja Católica, pretendeu-se delimitar cuidadosamente as contribuições dos semitas e as dos arianos, tratados a partir de então como dois grupos opostos e complementares. ${ }^{23}$

É pela voz desses autores que o politeísmo grego reconquistou seu direito de cidadania na filosofia. A noção de 'símbolo' proposta por eles respondia ao problema da separação entre o finito e o infinito, ao passo que a arte, veículo do simbólico, tornou-se uma espécie de chave interpretativa da experiência humana. Lembremo-nos particularmente das concepções de Herder e de Hei-

mitologia e a religião, de um lado, e a moral, de outro (apud DETIENNE, M. L'invention de la mythologie, p. 16-17; 38-44; 90-91).

22 A noção de 'civilização ariana' foi substituída posteriormente pelas de 'indo-germânica' e de 'indo-europeia', esta sendo a mais corrente atualmente (o termo 'indo-germânico' quase não sendo mais empregado hoje, com a exceção de alguns estudiosos alemães). Veja-se OLENDER, M. "Monothéisme et polythéisme au miroir indo-européen." In: SCHMIDT, F., org. L'impensable polythéisme. Etudes d'historiographie religieuse, Paris, 1988, p. 461-473, de onde colhemos a citação (p. 466). Veja-se especialmente p. 466-467, onde o autor resume a visão mais ou menos comum aos eruditos mencionados: «A mitologia politeísta consiste num sistema de representações complexas articulando o mundo de maneira a tornar visíveis a pluralidade e a riqueza.»

23 OLENDER, M. "Monothéisme et polythéisme au miroir indo-européen," p. 467: "Os Hebreus, nesse caso preciso 'Semitas' por excelência, são então considerados os que, durante muito tempo e com uma fidelidade tenaz, pela qual os felicitamos, conservaram a faísca monoteísta. Contudo, esta só pôde aparecer no esplendor do dia graças à dinâmica, totalmente ariana, da Igreja." OLENDER, M. Les langues du paradis. Aryens et Sémites: un couple providentiel. Paris: Gallimard / Le Seuil, 1989, p. 125-129. Para uma exposição ao mesmo tempo sucinta e crítica das teorias sobre o arianismo e o termo 'ariano', veja-se o verbete "Aryens" escrito por J. Varenne em POUPARD, P., org. Dictionnaire des Religions. Paris: Presses Universitaires de France, 1984, vol. 1, 1984 (3a ed. 1993), p. 126-128, em especial o seguinte comentário: 'O denominativo 'ariano' só concerne, stricto sensu, os Indianos e os Iranianos proto-históricos que, no começo do segundo milênio antes de nossa era, designavam-se a si mesmos como ârya (sânscrito), aïryo (avéstico), ou ariya (antigo persa). Essas línguas pertencem à família lingüística dita 'indo-europeia' (grego, latim celta, germânico, eslavo, balta, albanês, armênio, iranieno, sânscrito, etc.), veiculados por povos que, em vagas sucessivas, fizeram a conquista de uma vasta zona geográfica estendendo-se do Mar do Norte ao golfo de Bengala. [...] Portanto, ao termo da pesquisa aparece claramente que os ârya não eram nem 'nobres' nem indivíduos definindo-se eticamente como 'puros'. É verdade, por outro lado, que a palavra se referia a uma forma muito original de cultura detentora de um sistema de valores traduzindo uma visão do mundo particular. Um desses valores era o pertencimento à comunidade, com direitos e deveres cuidadosamente codificados." 
ne, para os quais os deuses das obras-primas da poesia e da escultura grega são símbolos no sentido mais elevado do termo.

Numa obra publicada em 1803, por exemplo, Friedrich Creuzer sustentou que a forma humana dos deuses é uma mudança trazida pela poesia e constitui uma necessidade do pensamento, que de outro modo é incapaz de atingir o infinito. ${ }^{24} \mathrm{O}$ autor guarda a noção de 'símbolo' dos humanistas alemães mas limita sua efetividade ao âmbito da arte. No que diz respeito à religião grega, sua abordagem centra-se sobretudo na noção romântica de 'instinto': fonte de toda expressão icônica, o simbólico seria o efeito de um 'instinto' (Trieb, Grundtrieb) e de uma 'obrigação' (Nöthigung). ${ }^{25}$

Ora, a tensão entre essas duas perspectivas principais na obra de Creuzer - a do 'símbolo' e a do 'instinto' - acabou levando-o a inverter as posições na valorização da mitologia e dos poemas homéricos: se inicialmente ele havia considerado a mitologia a expressão simbólica primitiva, precária diante da imagem de perfeição dos deuses homéricos, num segundo momento é aos mitos que o autor atribui a religiosidade mais autêntica. ${ }^{26}$ Este segundo momento

24 BRAVO, B. "Dieu et les dieux chez F. Creuzer et F. G. Welcker". In: SCHMIDT, F. , org. L'impensable polythéisme. Etudes d'historiographie religieuse. Paris: Editions des Archives Contemporains, 1988, p. 375-424. A obra mencionada é Die historische Kunst der Griechen in ihrer Entstehung und Fortbildung, de que Bravo traduz e cita a seguinte passagem (p. 382 do artigo, p. 16-17 da obra citada): "A epopeia recebeu toda essa riqueza do mito e deu aos mais diversos elementos do seu conteúdo uma bela forma humana. Ao lado do que a lenda contava dos homens do passado, o produto, originalmente grosseiro, de uma simbólica que personificava as forças da natureza, apareceu aqui enquanto deus sob uma forma tomada de empréstimo ao que a humanidade oferecia de melhor, e nas ações que eram a flor da vida heróica. Por conseguinte, é somente graças ao fato de que ela havia se atribuído limites humanos que a poesia tornou-se capaz de representar o divino."

25 BRAVO, B. "Dieu et les dieux chez F. Creuzer et F. G. Welcker", p. 384-387, que traduz e cita passagens da Symbolik und Mythologie der alten Völker, publicada em 1806 (p. 63 da obra, citação parcial): "Reconhecer o vivente por toda parte, eis o hábito mais específico dessa maneira de pensar. $E$ não somente seres vivos, mas também humanos. O que se manifesta de uma maneira tão universal, e especialmente numa época cujas representações não são desviadas do caminho da natureza por uma falsa cultura, já deveria por essa razão ser considerado um instinto natural e uma voz da natureza. Nós reconhecemos, portanto, uma imposição que obriga o homem a se colocar a si mesmo como centro do mundo e a ver em todos os reinos da natureza sempre e somente sua própria imagem refletida. [...] Portanto, o que o entendimento abstrato chama de força ativa é, para a maneira de pensar primordial e inocente, uma pessoa. Com isso é imediatamente dado o sexual, com todas as manifestações que dependem dele: o amor e o ódio, a união e a separação, tendo aquela a consequência imediata da procriação e do parto, e esta a morte e a destruição, bem como, por outro lado, a vida renasce da morte. Assim, o que nós chamamos de expressão icônica <Bildliches>, não é nada além da impressão da forma do nosso pensamento, uma imposição à qual nem mesmo o espírito mais abstrato ou o mais sóbrio poderia substrair-se, mas à qual a antiguidade tendeu mais a ficar ligada. Os monumentos dessa maneira icônica <bildliche Weise >, são as religiões do antigo passado, notadamente as religiões politeístas, e as obras de poetas antigos, cuja essência repousa na personificação de forças ativas e onde Eros, enquanto união personificada de forças ativas, desempenha um papel tão importante."

26 BRAVO, B. "Dieu et les dieux chez F. Creuzer et F. G. Welcker", p. 394-395. Além dessa hesitação de Creuzer sobre os valores relativos da mitologia e da epopeia, Bravo observa também (p. 388-389) uma ambiguidade a respeito da noção de 'símbolo', que designa às vezes o «produto da atividade plástica humana, servindo para exprimir uma ideia infinita» e a «ideia infinita que se manifestou numa forma finita». A distinção enttre 'símbolo' e 'alegoria' também não é sempre clara para o autor (ibidem, p. 391-392). 
de sua obra é igualmente marcado por uma grande valorização dos autores gregos que atacaram a religião tradicional, particularmente os que criticaram a representação homérica dos deuses. ${ }^{27}$

Influenciado pela crítica de Creuzer da religião homérica, F. G. Welcker também pôs em dúvida a capacidade do politeísmo de corresponder plenamente às necessidades espirituais humanas. $\mathrm{O}$ politeísmo grego seria o resultado necessário do esforço do espírito humano de explicar o divino. Ele é, portanto, obra da imaginação poética: tendo-se beneficiado da imensa difusão da poesia épica, ele se teria juxtaposto a uma crença monoteísta original. Ao lado do politeísmo grego antigo que conhecemos hoje, e numa época ainda mais recuada, seria preciso supor uma religião monoteísta, cujos vestígios materiais e os testemunhos diretos teriam simplesmente sumido. ${ }^{28}$

Embora seja uma criação posterior e, consequentemente, secundária tanto do ponto de vista cronológico quanto do de sua importância, o politeísmo seria essencial historicamente para Welcker, sobretudo por constituir "um pressentimento e um prelúdio do cristianismo". Sua grandeza na história da humanidade residiria especialmente no fato de que os deuses antropomórficos gregos teriam favorecido a «cultura moral que distingue a Grécia de todo o resto». ${ }^{29}$

27 BRAVO, B. "Dieu et les dieux chez F. Creuzer et F. G. Welcker", p. 396-403, cita o sexto capítulo do livro I da Symbolik und Mythologie der alten Völker, besonders der Griechen. In Vorträgen und Entwürfen, publicada em 1810. Veja-se especialmente a seguinte passagem, onde Creuzer avalia a contribuição da crí́tica da religião dos filósofos jônicos da época arcaica (p. 396-397 do artigo de Bravo, p. 208-211 da obra de Creuzer): "Homens iluminados <erleuchtet>, experimentando um sentimento de mal-estar diante da infeliz pluralidade na qual o Uno, o divino tinha sido fragmentado, exprimem dúvidas salutares, deploram a quantidade inumerável e o ridículo dos mitos [...]. Eram os mestres da filosofia jônica; estes reconheceram o prejuízo que a onipotência da poesia homérica causava à religião e à filosofia pela dominação consolidada do mito. Eles tentaram levar o espírito excitável dos gregos dessa mobilidade mítica à imobilidade-tranqüilidade, e da dispersão na pluralidade à contemplação do Uno, do Todo. Eles restabeleceram o símbolo, que tinha sido eliminado pela lenda loquaz, nos seus direitos [...] (itálicos meus)." No prosseguimento dessa crítica da religião grega, Creuzer valoriza o orfismo, a interpretação néo-platônica da mitologia grega e a dimensão especulativa das religiões míticas em geral. Nessa investigação, que Bravo qualifica de "romantismo neo-platonizante, 'naturphilosophisch', 'naturmystisch'” (ibidem, p. 403), Creuzer não evitou certos excessos, notadamente no que concerne a ausência de crítica das fontes antigas utilizadas. Veja-se também SNELL, B. A descoberta do espírito. Lisboa: Edições 70 , 1992, p. 48-49, para quem Creuzer "projetou na época clássica e pré-clássica elementos datando do fim da antiguidade".

28 BRAVO, B. "Dieu et les dieux chez F. Creuzer et F. G. Welcker", p. 412-414. Veja-se a seguinte passagem do primeiro tomo da Griechische Götterlehre, publicada em Götingen em 1857 (citada e traduzida por Bravo, p. 412 = p. 229-229 da obra de Welcker): "A ideia primeira e a mais natural - aquela à qual a abstração retornará em seguida - é que o Todo é animado, que o corpo do mundo, assim como o corpo humano, é vivificado, movido e dominado por um ser invisível; é mais difícil supor que a noção de partes vivas ergueu-se à de uma vida do Todo, que se passou dos deuses a Deus. A 'insitia notitia' é Deus e não os deuses; estes são a obra de pensamentos humanos e a formação humana da linguagem."

29 BRAVO, B. "Dieu et les dieux chez F. Creuzer et F. G. Welcker", p. 415-416, que se refere à Griechische Götterlehre, p. 255-257, e também remete às p. 245 e 250-251. Observe-se ainda que a dificuldade de se aceitar o politeísmo e a de compreender a amoralidade dos deuses gregos são apenas os dois aspectos complementares do mesmo fenômeno. 
De uma forma ou de outra, vê-se que Creuzer e Welcker nunca observaram o politeísmo grego independentemente de certos pressupostos metafísicos, notadamente da exigência de uma unidade transcendente e fundamental a sustentar todo procedimento de reflexão com pretensão à racionalidade. Welcker defendeu que a posição de Zeus no panteão grego era uma sobrevivência da crença monoteísta primordial. ${ }^{30}$ Para esses dois influentes autores, o politeísmo grego não passaria de um epifenômeno da espiritualidade humana, pois muito aquém da sua verdadeira expressão na crença monoteísta. ${ }^{31}$

Os pressupostos negativos contra a visão pluralista do antropomorfismo religioso também marcaram as obras de Johann Gottfried Herder (1744-1803) e de Ernest Renan (1823-1892). O primeiro aliou o relativismo cultural à visão providencial da história, oscilando entre uma visão igualitária dos povos e julgamentos severos a seu respeito. Em Sobre o espírito da poesia hebraica (1782-1783), o personagem Alcífron obtém o assentimento de Eutífron, seu interlocutor, ao perguntar: "Não é para evitar o politeísmo, próprio a todas as nações incultas, que Moisés conjuga o plural Elohim no singular, na fórmula 'Elohim criou'?" Segundo J. G. Herder, a poesia hebraica seria fruto de um gênio humano e divino diretamente relacionado com o monoteísmo que ela transmite. ${ }^{32}$

Ernest Renan sustentou que a religião monoteísta era o segredo sublime que tinha fugido para a terra estéril de Israel, como comprovava sua má administração pelos semitas. ${ }^{33}$ Em L'avenir de la science (1848-1849), defendeu a incompatibilidade entre o monoteísmo e a língua hebraica que o veiculava, por ser esta privada de sintaxe e portanto incapaz de manejar a inversão que permite à frase ariana conservar a ordem natural das ideias sem prejudicar as relações gramaticais. ${ }^{34}$ As línguas semíticas seriam incapazes de formular e, em decorrência, de pensar o múltiplo que caracteriza a inteligência polivalente

30 BRAVO, B. "Dieu et les dieux chez F. Creuzer et F. G. Welcker", p. 405.

31 Creuzer teve uma influência decisiva sobre Welcker no que concerne a teoria de uma transformação do mito pela poesia homérica. À parte isso, há numerosas outras diferenças entre os dois autores. Se saliento as semelhanças entre eles, é sobretudo para enfatizar a dificuldade de se compreender o politeísmo grego que marcou frequentemente as discussões nos séculos XVIII e XIX. Veja-se BRAVO, B. Dieu et les dieux chez F. Creuzer et F. G. Welcker, p. 416-418, que destaca dois aspectos principais: (1) para Creuzer haveria uma ciência teológica primitiva dos povos mais antigos, caracterizada pelo panteísmo, pela emanação e pela consciência discursiva, enquanto para Welcker haveria um monoteísmo primitivo; (2) para Creuzer o politeísmo grego consistiria fundamentalmente numa religião da imaginação, ao passo que para Welcker tratar-se-ia de uma religião da natureza.

32 OLENDER, M. Les langues du paradis. Aryens et Sémites: un couple providentiel, p. 68-97.

33 OLENDER, M. Les langues du paradis. Aryens et Sémites: un couple providentiel, p. 106-121; em particular p. 112, onde o autor resume a posição de Renan: "Nesse século XIX em que tudo se mede pelo potencial da história, pela intensidade teleológica da evolução e do progresso, é a estagnação semítica que caracteriza a essência do milagre monoteísta."

34 OLENDER, M. Les langues du paradis. Aryens et Sémites: un couple providentiel, p. 122-132. 
da natureza. Já o politeísmo dos arianos revelaria o acordo de sua língua com a religião, o que veio a ser confirmado pela composição dos poemas épicos. Sopesando vantagens e desvantagens, E. Renan posicionou-se pela superioridade dos arianos, bem como por um julgamento ambíguo acerca do cristianismo, mas não a ponto de negá-lo. ${ }^{35}$

Mesmo com o desprestígio das concepções filosóficas e religiosas românticas, a suspeita da autenticidade do antropomorfismo divino não abandonou as teorias sobre a origem da religião grega. No início do século XX, P. W. Schmidt, da Escola Etnográfica de Viena, procurou ainda demonstrar a existência de um monoteísmo primordial em seu Der Ursprung des Gottesidees. ${ }^{36}$ Mais tarde, a Escola de Cambridge procurou em vão nos novos dados arqueológicos sobre a cultura minoica um passado religioso onde não haveria lugar para o antropomorfismo ou o politeísmo dos poemas homéricos. ${ }^{37}$

Em 1923 F.-M. Cornford apresentou sua coletânea de textos antigos sobre a religião grega afirmando que "do século sexto em diante o leitor vai discernir uma mudança brusca na direção do monoteísmo. Zeus se torna menos antropomórfico, o pai da família desregrada do Olimpo [...]". A figura de Zeus é certamente complexa e sua importância como deus ordenador influenciou uma reflexão sobre a realidade em que a busca de uma racionalidade autorregulativa foi determinante. ${ }^{38}$ Todavia, se Cornford tem razão ao dizer que «o movimento de pensamento na ciência da natureza começa de um ponto tão remoto quanto possível do vigoroso antropomorfismo de Homero na cabeça da tradição poética», revela certo preconceito quanto à antiguidade do antropomorfismo quando tenta caracterizar os pensadores jônicos:

“Talvez não seja comumente reconhecido que, ao reduzir 'o divino' a essa substância viva impessoal, os filósofos estivessem, sem o saber, retornando para uma concepção de divindade imensamente mais velha do que o antropomorfismo homérico. Eles

35 OLENDER, M. Les langues du paradis. Aryens et Sémites: un couple providentiel, p. 106-146.

36 ELIADE, M. Traité d'histoire des religions. Paris: Payot, 1964 (2a ed. 1986), p. 46.

37 BURKERT, W. Griechische Religion der archaischen und klassischen Epoche, p. 76: "Procurou-se e logo se encontrou a antítese do mundo divino 'olímpico', antropomórfico e politeísta homérico: potências ctônicas predominantes, matriarcado, divindades com formas não-humanas ou então uma única figura divina no lugar de um panteão. Mas tais suposições e hipóteses só se confirmaram numa medida muito pequena." $\mathrm{O}$ autor cita em particular a tese de Sir Arthur Evans, refutada logo depois, segundo a qual haveria um culto minóico da árvore e da coluna. Em seu Tradition and design in the 'lliad', Oxford, 1930, p. 218-220, C. M. Bowra ainda defendia a compreensão da teologia homérica como uma etapa na transição da adoração dos animais para a de figuras humanas.

38 Cf. também VLASTOS, G. "Theology and philosophy in early greek thought," p. 6, sobre os pensadores jônicos: "Eles começaram com a fé de que a própria natureza era animada por essa Sabedoria e Justiça que a consciência mais iluminada de sua raça havia imputado a Zeus. Enquanto essa fé vivia, eles puderam transferir para a natureza a reverência até então reservada a Zeus e puderam consequentemente chamar a natureza 'deus' sem incorrer numa figura de linguagem vazia." 
estavam desfazendo todo o trabalho dos poetas e dos artistas plásticos, e redescobrindo o material cru a partir do qual os deuses humanizados tinham sido construídos." 39

Não vejo como comprovar historicamente que as crenças antropomórficas sejam mais recentes do que algum tipo de crença impessoal grega anterior ao "trabalho dos poetas e dos artistas plásticos". Parece-me, ao contrário, que tais afirmações apenas perpetuam um equívoco que, como mostrei, remonta pelo menos ao início do século XIX.

Um outro exemplo desse tipo de distorção nos é dado por R. B. Onians em seu livro The origins of european thought, de 1954, quando afirma que "Homero está a caminho para uma causa única eficiente, theós, o deus Zeus, mas sobrevive o grande número, cada um para a sua espécie." ${ }^{40}$ A soberania de Zeus só tem sentido no seio da pluralidade dos deuses e caracteriza, portanto, essencialmente a religião grega. Por outro lado, a vontade de Zeus é uma marca determinante de seu comportamento humano em Homero e em Hesíodo, não podendo ser reduzida a nenhuma noção de 'causalidade'. Como prever o que quer Zeus? Só para citar o exemplo mais evidente, a 'deliberação de Zeus' (Diòs boulé) anunciada em Ilíada, I, 5 é plenamente apresentada ao longo do poema como uma vontade, quer dizer, tanto como fruto de sua deliberação quanto de um impulso insondável, para os heróis assim como para nós, leitores. ${ }^{41} \mathrm{~A}$ ideia de que "Homero está a caminho para uma causa única eficiente" é, portanto, infundada, não passando de uma tentativa pouco sutil de considerar a Ilíada e a Odisseia representantes de uma forma menos evoluída de pensamento. ${ }^{42}$

Mais recentemente, J. Rudhart também revelou certos preconceitos teóricos ao concluir suas "Considérations sur le polythéisme" afirmando que "a palavra 'politeísmo' é, portanto, ambígua” e que as religiões politeístas "reconhecem ao seu modo a unidade do divino". ${ }^{43}$

39 CORNFORD, F. M. Greek religious thought, "Introduction", p. xvii-xviii e xx-xxii.

40 ONIANS, R. B., The origins of european thought. About the body, the mind, the soul, the world, time and fate. Cambridge: Cambridge University Press, 1951 (2ª ed. 1954), p. 466.

41 ROUSSEAU, P. "L'intrigue de Zeus", Europe, 865, 2001, p. 120-158.

42 Este é só um dentre os muitos exemplos de estudiosos do século XX que se referem a Aristóteles como parâmetro último e definitivo para a racionalidade grega. Tratei da complexidade da representação poética de Zeus em DOURADO-LOPES, A. O. "Zeus na religião grega: hegemonia, antropomorfismo e atividade celeste nos testemunhos de Homero e de Hesíodo." Nuntius Antiquus, III, 2009, p. 1-16. Para uma avaliação do despropósito da afirmação de F. M. Cornford, basta consultar-se o estudo de M. Vegetti sobre a formação da noção de causalidade no século V a. C.: VEGETTI, M. "Culpability, responsibility, cause: philosophy, historiography, and medicine in the fifth century." In: LONG, A. A., org., The Cambridge companion to early Greek philosophy. Cambridge: Cambridge University Press, 1999, p. 271-289.

43 RUDHART, J. "Considérations sur le polythéisme". Revue de Théologie et de Philosophie, 16, 1966, p. 353-364; p. 364 para a citação. Para sustentar essas considerações, o autor cita uma passagem de Celso: "Longe de ensombrecer Deus, aquele que serve diversos deuses Lhe é agradável, porque seu zelo 
Uma exceção à negligência a respeito da importância e das especificidades do antropomorfismo divino é o estudo de J.-P. Vernant, "Aspects de la personne dans la religion grecque":

"O panteão grego se constituiu numa época do pensamento que ignorava a oposição entre sujeito humano e força natural, que ainda não tinha elaborado a noção de uma forma de existência puramente espiritual, de uma dimensão interior do homem. Os deuses helênicos são Potências, não pessoas. [...] Uma potência divina não tem realmente 'existência para si'. Ela só tem ser pela rede de relações que a une ao sistema divino no seu conjunto. E nessa rede ela não aparece necessariamente como um sujeito singular, mas também como um plural: seja pluralidade indefinida, seja multiplicidade numerada. Entre essas formas para nós exclusivas uma da outra - uma pessoa não poderia ser muitas -, a consciência religiosa do grego não estabelece uma incompatibilidade radical. [...] Segundo os momentos e as necessidades, a mesma potência divina será considerada na sua unidade, no singular, na sua multiplicidade de aspecto, no plural. [...] A razão desse paradoxo, é precisamente que um deus exprime os aspectos e os modos de ação da Potência, não as formas pessoais de existência. Do ponto de vista da Potência, a oposição entre o singular e o universal, o concreto e o abstrato, não interfere." 44

O estudo de J.-P. Vernant tem o mérito de salientar a indissociabilidade entre a pluralidade e o antropomorfismo do panteão grego: só é possível pensar o humano como uma sociedade. Todavia, na medida em que não demarca as particularidades da perspectiva homérica, sua argumentação perde precisão histórica. Na passagem acima, a referência ao antropomorfismo divino como fruto de "uma época [...] que ainda não tinha elaborado a noção de uma forma de existência puramente espiritual" (itálico meu) parece sugerir a ideia de uma evolução das crenças gregas que mais uma vez relega o antropomorfismo

tem por objeto algum dos seres que Lhe dizem respeito; com efeito, não é possível que alguém receba homenagens, sem que esse privilégio seja concedido por Ele...» (p. 363). No parágrafo conclusivo, de onde extraio as expressões citadas, Rudhart parece querer desculpar a religião grega por ser politeísta: «A palavra politeísmo é, portanto, ambígua. Ela é cômoda e legítima porque designa um tipo de religião em que os procedimentos do pensamento diferem dos que caracterizam as religiões oriundas da Revelação mosaica, mas ao empregá-la é preciso saber que, se tais religiões honram diversos deuses, elas o fazem num espírito sutil, com uma piedade prudente, e reconhecendo à sua maneira a unidade do divino." $\mathrm{O}$ mesmo se pode dizer de KIRK, G. S. The Iliad: a commentary. Volume II: books 5-8. Editor geral G. Kirk. Cambridge: Cambridge University Press, 1990; "Introduction”, p. 13-14, que observa a respeito do ângulo pelo qual os poemas homéricos mostram a religião grega: "O politeísmo era apresentado na sua forma mais benéfica, Zeus oferecendo um princípio de ordem - e mesmo, para aqueles que o consideram uma vantagem (e os gregos a seu modo o faziam com certeza), um núcleo monoteísta. É uma consideração que é preciso ter firmemente no espírito quando se reage a alguns dentre os papeis e as reações mais humanas e os menos elevados dos deuses e das deusas da llíada." A expressão 'núcleo monoteísta' me parece propiciar um grande equívoco e é, infelizmente, suficientemente vaga para permitir ao autor esquivar-se a toda refutação baseada em evidências textuais. É o tipo de afirmação imprecisa que conta com as inclinacões de um público impregnado por séculos de erudição cristã.

44 VERNANT, J.-P. "Aspects de la personne dans la religion grecque". In: VERNANT, J.-P. Mythe et pensée chez les Grecs. Etudes de psychologie historique, Paris, 1965 (2ª ed. 1990), p. 267-282; p. 273-276 para a citação. 
à condição de estado provisório e, nesse sentido, inferior. É como se desde o início o antropomorfismo fosse uma experiência religiosa insuficiente fadada a desaparecer. Não vejo como fundamentar na cultura grega um julgamento dessa natureza.

O contexto da época arcaica é outro. Justamente por suas características racionalizantes, o antropomorfismo divino não poderia deixar de afetar-se pelas novas exigências da racionalidade impessoal propugnada pelos pensadores jônicos, ainda que perdurasse no culto e na poesia. Essa nova racionalidade distanciava-se do antropomorfismo da religião grega, mergulhando na reflexão sobre a natureza que os poemas homéricos remetiam aos deuses. ${ }^{45}$ Criou-se, assim, uma ambiguidade no discurso sobre a religião, que Heráclito assumiu com todas as letras ao afirmar que «uma só (coisa) o sábio, não quer e quer ser dito com o nome de Zeus». ${ }^{46} \mathrm{~A}$ ambiguidade é, portanto, constitutiva desse momento da experiência religiosa grega. Se J.-P. Vernant tem razão ao observar que a relação pessoal homem-deus é um excesso, uma hybris, seu texto perde em clareza ao propor uma noção de 'Potência' ('Puissance') como tradução e, de certo modo, síntese da experiência grega de divindade. ${ }^{47}$ Não me parece que este termo corresponda a alguma palavra grega da época arcaica que pudesse referir-se aos deuses. ${ }^{48} \mathrm{Na}$ medida em que são atuantes

45 VLASTOS, G. "Theology and philosophy in early greek thought", p. 24-25: "Apresentar a divindade como inteiramente imanente na ordem da natureza e, portanto, absolutamente obediente às leis era a contribuição religiosa peculiar e distintiva dos pré-socráticos, e deveria ser colocada na fachada de todo relato de seu pensamento religioso. Eles tomaram uma palavra que na fala comum era o umbral do irracional, antinatural e incontável e tornaram-na o nome de um poder que se manifesta na operação, não na perturbação, da lei inteligível."

46 Fragmento B 32 DK, transmitido por Clemente de Alexandria, Tapeçarias, V, 105: hèn tò sophòn moûnon légesthai ouk ethélei kaì ethélei Zenòs ónoma. Trad. de J. C. de Souza em DE SOUZA, J. C., org. Présocráticos. Fragmentos, doxografia, comentários. Volume I. Coleção "Os pensadores". São Paulo: Nova Cultural, 1989, p. 54, modificada. Cf. também a tradução de D. Schüler em SCHÜLER, D. Heráclito e seu (dis)curso. Porto Alegre: L\&PM Pocket, 2000, p. 40: "O um, o saber exclusivo, não quer e quer ser chamado pelo nome de Zeus". O mesmo tradutor comenta: "Heráclito reabsorve o particular no divino, despersonalizando fenômenos para evitar a noção da infinidade de essências autônomas que a proliferação de deuses sugere." A observação de D. Schüler é pertinente mas parcial, pois parece-me que não é apenas a pluralidade que Heráclito quer evitar, mas a própria associação do divino à figura humana que, embora venha normalmente associada à pluralidade - todo antropomorfismo é politeísta e vice-versa -, não precisa reduzir-se a ela. Ver também o fr. B 67 DK, que fala do deus (ho theós) e termina com as palavras (tradução por J. C. de Souza da edição citada acima): [...] onomázetai kath "hedonèn hekástou. / "[...] e se denomina segundo o gosto de cada".

47 VERNANT, J.-P. "Aspects de la personne dans la religion grecque", p. 272-273 e 276-277, onde o autor se refere ao dionisismo, aos cultos de mistério, à adoração de ídolos e ao culto dos mortos.

48 'Dynamis' seria o termo mais próximo da 'Potência' de J.-P. Vernant mas não aparece nos textos que nos chegaram da época arcaica (embora o verbo 'dynamai', que o origina, já apareça em Homero). Cf. LEFEBVRE, D. Capacité, force et puissance. Sur la genèse et les sens de la notion aristotélicienne de dynamis. Tese de doutorado em Filosofia. Paris: Université de Paris I, 2000. Quanto a 'ís' e 'bíe', que exprimem 'força' e 'poder' dos elementos naturais - is anémou (llíada, XV, 383, etc.), is anémoio (Ilíada, XVII, 739; Odisseia, IX, 71; XIII, 276; XVIII, 60 e 405, etc.), is potamoîo (Ilíada, XXI, 356), is Eelíou (Odisseia, XII, 175-176, etc.), - e também são empregados como denominações perifrásticas dos heróis homéricos - 
e, por vezes, protagonistas da narrativa, os deuses homéricos não são menos caracterizados como personagens do que os heróis. ${ }^{49}$

$\mathrm{O}$ rápido percurso que propus aqui põe em evidência uma certa continuidade entre os estudiosos antigos e modernos de Homero, mais especificamente, e da religião grega, em geral, no que diz respeito à sabedoria contida nas narrativas sobre a participação divina nos acontecimentos que passaram a ser descritos como 'naturais'. A participação divina passou a ser considerada produto de uma ficção poético-religiosa incompatível com a racionalidade impessoal que se impôs definitivamente como exigência do verdadeiro conhecimento. Essa complexa e longa operação intelectual da Grécia arcaica não decorreu propriamente da transformação das crenças religiosas, mas da criação de uma fronteira entre estas e uma noção de conhecimento natural em vias de se consolidar e reivindicando total autonomia. Conhecer tornou-se se incompatível com desejar. Os novos sábios deixaram de lado o tom persuasivo com que sacerdotes e adivinhos dirigiam-se aos deuses e passaram a antecipar diretamente a realidade, sentenciando para seu público as verdades fundadas na sua peculiar observação da experiência. A influência sobre o futuro continuou a ser a marca distintiva da sabedoria, mas a partir de então o sábio não mais pleiteava o privilégio da atenção divina, como, por exemplo, Crises e Calcas no imponente início da Ilíada ${ }^{50} \mathrm{O}$ sábio passou a distinguir-se pela certeza sobre acontecimentos até então alheios à compreensão humana,

is Odysêos (Ilíada, XXIII, 720, etc.), is Telemákhoio (Odisseia, II, 409 e XVI, 476, etc.), bíe Herakleíe (Ilíada, XI, 690, etc.), bíei Heraklêos (Ilíada, XVIII, 117), bíe th'Helénoio ánaktos (Ilíada, XIII, 770 e 781, etc.), bíe Hyperénoros hippodámoio (Ilíada, XVII, 24), Aineíao bíe (Ilíada, XX, 307, etc.), etc. -, não têm na época arcaica o sentido religioso indicado por J.-P. Vernant. O mesmo se pode dizer dos termos 'krátos' (Ilíada, VII, 142; X, 156; XVI, 54; etc.) e 'alké' (Ilíada, III, 45; IV, 245; V, 532; VIII, 140; IX, 706, etc.). Portanto, a expressão com que J.-P. Vernant pretende conciliar os opostos da figura humana e da abstração conceitual como características da divindade é anacrônica e imprecisa no que diz respeito à época arcaica, embora não à clássica.

49 Dentre a vasta bibliografia sobre o assunto, leia-se ERBSE, H. "Über Götter und Menschen in der Ilias Homers", Hermes, 124, 1996, p. 1-16; em particular p. 9-10: "o acontecimento terrestre aparece como uma imagem refletida dos planos celestes. A ação humana é então sempre executada quando está de acordo com a vontade dos deuses, e gregos e troianos podem esperar a ajuda do céu, já que eles efetuam os desejos de seus protetores imortais. Todavia, como o mostra particularmente a llíada, esses desejos decorrem de motivos puramente humanos: amor, ódio, simpatia, desprezo, preferência, frieza. Os deuses perseguem seus objetivos como homens, só que com mais sucesso, de maneira mais brutal e ao mesmo tempo mais lúdica, como agem essências que não conhecem a última gravidade, a morte."

50 Ilíada, I, 7-100. A relação da sabedoria com a previsão do futuro é salientada por CORNFORD, F. M. Principium sapientiæ. As origens do pensamento filosófico grego. Trad. por M. M. R. Santos. Lisboa: Fundação Calouste Gulbenkian, 1975; em particular os capítulos V a VIII. DETIENNE, M. Les maîtres de vérité dans la Grèce archaïque. Paris: Pocket, 1985; ver em particular p. 55-56, o comentário à fórmula épica tá t'eónta tá t'essómena pró t'eónta (lliada, I, 70 e Hesíodo, Teogonia, 38; em Teogonia, 32 a expressão é restringida aos tempos não presentes: tá t'essómena pró t'eónta). 
como o movimento dos astros, a alternância das estações e o funcionamento do corpo animal. ${ }^{51}$

Substituiu-se a tentativa de persuasão pela afirmação, a expectativa pela certeza, e a própria sabedoria pôde ser atribuída a um 'sábio' impessoal, tò sophón, segundo o fr. B 41 DK Heráclito: "Pois uma só é a (coisa) sábia, possuir o conhecimento que tudo dirige através de tudo". ${ }^{52}$ Essa formulação de Heráclito veio a ser apenas o prenúncio do profícuo recurso filosófico de substantivação de adjetivos para exprimir propriedades abstratas, tão determinante para o pensamento de Platão e de Aristóteles. ${ }^{53}$ A ousadia de Heráclito não consistiu apenas em substantivar um adjetivo a partir de sua forma neutra, formando uma compreensão abstrata, mas em extrair de um termo aplicado exclusivamente a homens um sentido impessoal. Pela primeira vez se pensou que a sabedoria, para ser experimentada por um só homem, precisava estar de algum modo disponível e, nesse sentido, ser comum a todos os homens. ${ }^{54}$ Para

51 Evidentemente, emprego aqui o termo 'sábio' em sentido amplo. As ocorrências mais antigas da raiz soph- são llíada, XV, 412 (eû eidêi sophíes hypothemosyneisin Athénes) e Hesíodo, Os Trabalhos e os dias, 649 (oúté ti nautilíes sesophisménos oúté ti neôn) e fr. 306 Merkelbach-West, linha 1 (pantoíes sophíes dedaekóta). Nas três passagens, os termos remetem a algum conhecimento prático ou a todos em geral: construção, na llíada, navegação e conhecimentos técnicos em geral, em Hesíodo. Cf. SNELL, B. Der Weg zum Denken und zur Wahrheit. Studien zur frühgriechischen Sprache. Hypomnemata. Untersuchungen zur Antike und zu ihrem Nachleben, 57. Göttingen: Vandenhoeck \& Ruprecht, 1978, capítulo 2: "Wie die Griechen lernten, was geistige Tätigkeit ist", p. 21-43; à p. 32 o autor observa sobre llíada, XV, 412: "Aqui eidenai remete à prática, como na expressão oîde máchesthai." Ver também o comentário de M. West em HESíODO. Hesiod. Works and days. Edição, notas e comentários por M. West. Oxford: Clarendon Press, 1978, ad 649.

52 hèn tò sophón, epístasthai gnómen, hotée ekybérnese pánta dià pánton. Trad. de J. C. de Souza em SOUZA, J. C. de, org. Pré-socráticos. Fragmentos, doxografia, comentários. Volume I. Coleção "Os pensadores". São Paulo: Nova Cultural, 1989, p. 55. Ao que parece, Heráclito é o primeiro a empregar o adjetivo sophós no gênero neutro. Acrescente-se a esse, dois outros fragmentos em que o mesmo adjetivo qualifica um infinitivo: fr. B 50 DK (...homologeîn sophón estin hèn pánta eînai) e B 108 DK (...hóste ginóskein hóti sophón esti pánton kekhorisménon.). Assim como a substantivação no B 41, o emprego de sophós no neutro como qualificativo dos infinitivos homologeîn e ginóskein em B 50 e B 108 indica a intenção de chamar a atenção para a impessoalidade da verdadeira sabedoria, invertendo o emprego pessoal habitual do termo. Para ocorrências posteriores da substantivação de sophós com o artigo neutro ou como qualificativo de um infinitivo ou de um pronome neutro indeterminado (ti, oúti, oudén), vejase, por exemplo, Heródoto, III, 36, 4 (sophòn dè he promethíe) e V, 18, 19 (hoi Pérsai [...] phámenoi tò poiethèn toûto ouk eînai sophón); Sófocles, Filoctetes, 1244 (sophòs pephykòs oudèn exaudáis sophón); Antígona, 364 (Sophón ti tò mechanóen / téchnas hypèr elpíd 'échon / toté mèn kakón, állot'ep'esthlòn hérpei); Eurípides, Heráclidas, 879-882 (atár ti keúthon lóleos sophón pote / Eurusthéos epheísat ' hóste mè ktaneîn; / léxon' par ' hemîn mèn gàr ou sophón tóde / echthroùs labónta mè apoteísasthai díken.). Para a importância da persuasão, veja-se o que diz Nestor a Agamêmnon e Aquiles em Ilíada, I, 274 (allà peíthesthe kaì ymmes, epeì peíthesthai ámeinon), bem como a referência de cada um à persuasão em suas respectivas respostas (llíada, I, 289 e 296).

53 GUTHRIE, W. K. History of Greek Philosophy. Volume IV: Plato's early dialogues, p. 119-121; SNELL, B. op. cit., capítulo 1: "Der Weg zum abstrakten Denken", p. 9-20; em particular p. 9-10. Para D. Furley, esse é um dos aspectos mais importantes e mais difíceis da tradução de textos filosóficos gregos para as línguas modernas (FURLEY, David. "Translation from greek philosophy." In: VÁRIOS. Aspects of translation. Studies in communication 2. London: Secker and Warburg, 1958, p. 52-64; em particular p. 60-63).

54 Observe-se a importância do termo 'comum' (xynós, koinós) nos fragmentos B 2, B 89, B 103, B 113 e B 114 DK, assim como de 'para todos' (pâsi, dativo plural de pâs) no fr. B 116 DK. 
impor-se a todos, esse 'sábio', tò sophón, a 'coisa sábia' precisava independer de qualquer vontade individual: a vontade perdeu a importância que tinha na perspectiva antropomórfica da realidade.

Na Grécia arcaica, com a desvalorização do antropomorfismo religioso, a experiência da vida em comum perdeu o antigo prestígio dos poemas homéricos, em que os principais heróis interagiam com os deuses das mais variadas formas. Nesse contexto, a palavra era ao mesmo tempo humana e divina. Quando, por exemplo, Atena se propõe a dissuadir Aquiles de matar Agamêmnon, conclui consultando-o: ai ke pitheai, "se te persuadires". ${ }^{55}$ Mesmo provindo da deusa, as palavras precisam persuadir. Algo de sua força se perdeu quando - com suas razões específicas na Antiguidade e na modernidade - a recusa da experiência religiosa do antropomorfismo divino confinou as palavras no mundo dos mortais. Nessas épocas - e em todas que cultivaram e vierem a cultivar o mesmo distanciamento - o sábio isola-se do convívio humano.

55 Ilíada, I, 207-208: êlthon egò paúsousa tò sòn ménos, aí ke pítheai / ouranóthen. Em enjambement, ouranóthen salienta tanto a importância quanto o engajamento da iniciativa da deusa e de Hera. SNELL, B. Die Entdeckung des Geistes. Studien zur Entstehung des europäischen Denkens bei den Griechen. Göttingen: Vandenhock \& Ruprecht, $1975^{4}$, p. 52, comenta essa passagem: "Que amabilidade distinta nessas três curtas palavras! Tal linguagem supõe formas sociais aristocráticas: é por sua cortesia e por seu espírito cavalheiresco que alguém demonstra consideração pelos outros e refreia suas próprias exigências. A mesma nobreza, a mesma civilidade regulam igualmente as relações dos imortais com os mortais. $O$ deus grego, com seus ventos e tempestades, não agride o homem com seus raios, e o homem não fica horrorizado com sua própria fraqueza diante da divindade. Atena fala com Aquiles como falaria com seus semelhantes: 'Segue-me, se quiseres.' E, livre e seguro, Aquiles responde: 'Pois bem, mesmo quando se experimenta a cólera é preferível seguir os deuses.' Em toda parte em Homero as situações são tais que o deus, quando aparece, não vem humilhar os humanos, nem esmagá-los, mas os eleva, ao contrário, os torna livres, fortes, corajosos e seguros de si. Em toda parte em que se realiza algo de grande e de decisivo, o deus aparece, dá suas instruções, e o humano que foi eleito para uma ação avançará em toda confiança." Veja-se também o comentário de M. Willcock à sua edição da llíada (The lliad of Homer. Edição e notas por M. M. Willcock. Londres: St Martin's Press, 1978, vol. I, ad loc.): "Observemos como Homero preserva a dignidade de seus personagens. A deusa pode advertir, mas não obriga; a decisão e a responsabilidade continuam com Aquiles." No mesmo sentido vai também o comentário a essa passagem de BURKERT, W. Griechische Religion der archaischen und klassischen Epoche, p. 292. KULLMANN, W. Das Wirken der Götter in der llias. Untersuchungen zur Frage der Entstehung des homerischen Götterapparats. Berlin: Akademie, 1956, salienta com freqüência a liberdade que os deuses deixam aos homens, apesar de sua influência sobre eles. Ver especialmente p. 149: "A parenese [do grego 'parénesis', 'exortação'] que deixa sempre ao homem sua própria decisão e apenas influencia suas ações sem determiná-las rigidamente, revela-se a forma mais característica da atividade divina na Ilíada." Veja-se ainda Kirk (G. S.), The lliad: a commentary. Volume I: books 1-4 (editor geral G. Kirk). Cambridge: Cambridge University, 1985, ad loc., para quem a expressão aí ke pítheai - que aparece outras quatro vezes na llíada e uma na Odisseia - teria sido presumivelmente (ingl. 'presumably') formada para a persuasão mortal mais do que para a divina. Não partilho dessa opinião, dado que a presença divina entre os homens e os diálogos entre os deuses, tão numerosos e tão decisivos em Homero, conferem às palavras como um todo dimensão ao mesmo tempo divina e humana. A opinião de G. S. Kirk seria, na verdade, mais um exemplo da visão, criticada neste estudo, de que o antropomorfismo divino distorce o verdadeiro sentimento religioso grego. Na medida em que são representados como humanos, os deuses acabam sujeitando-se invitavelmente às leis que governam a convivência humana, das quais a persuasão não poderia excluir-se. 


\section{Referências}

BRAVO, B. Dieu et les dieux chez F. Creuzer et F. G. Welcker. In: SCHMIDT, F. , org. L'impensable polythéisme. Etudes d'historiographie religieuse. Paris: Editions des Archives Contemporains, 1988, p. 375-424.

BURKERT, W. Griechische Religion der archaischen und klassischen Epoche. Stuttgart: Kohlhammer, 1977.

CALIFF, D. J. Metrodorus of Lampsacus and allegory: an extreme case? Arethusa, 36, 2003, p. 26-27.

COULOUBARITSIS, L. Aux origines de la pensée européenne. De la pensée archaïque au néoplatonisme. Bruxelles: De Boeck, 1992.

CORNFORD, F. M. Greek religious thought. Londres: J. M. Dent \& Sons, 1923.

CORNFORD, F. M. Principium sapientice. As origens do pensamento filosófico grego. Trad. por M. M. R. Santos. Lisboa: Fundação Calouste Gulbenkian, 1975.

DETIENNE, M. L'invention de la mythologie. Paris: Gallimard, 1981.

DIÓGENES LAÉRCIO. Diogenes Laertius. Lives of eminent philosophers. Edição, tradução, introdução e notas por R. D. Ricks., Londres / Cambridge (MA), 1959, 2 vol.

DIÓGENES LAÉRCIO. Diogène Laërce. Vies et doctrines des philosophes illustres. Traduction par M.-O. Goulet-Cazé, R. Goulet et M. Narcy. Paris: Le Livre de Poche, 1999.

DOURADO-LOPES, A. O. A força e o antropomorfismo dos deuses gregos. Considerações sobre a religião dos poemas homéricos. Aletria, v. 20, n. 2: "Os clássicos", julho-dezembro de 2009, p. 11-27.

ELIADE, M. Traité d'histoire des religions. Paris: Payot, 1964 (2a ed. 1986).

ERBSE, H. Über Götter und Menschen in der Ilias Homers. Hermes, 124, 1996, p. $1-16$.

FINLEY, M. I., Grécia primitiva: idade do bronze e idade arcaica. Trad. por W. R. Vaccari. São Paulo: Martins Fontes, 1990, p. 149-150.

FURLEY, David. Translation from greek philosophy. In: VÁRIOS. Aspects of translation. Studies in communication 2. London: Secker and Warburg, 1958, p. 5264.

HERÁCLITO. Tradução de D. Schüler. Heráclito e seu (dis)curso. Porto Alegre: L\&PM Pocket, 2000.

HESÍODO. Hesiod. Works and days. Edição, notas e comentários por M. West. Oxford: Clarendon Press, 1978.

JÆGER, W. Die Theologie der frühen Griechischen Denker. Stuttgart: Kohlhammer, 1964.

KENNEDY, G. A. Language and meaning in Archaic and Classical Greece. In: KENNEDY, G. A., org. The Cambridge history of litterary criticism. Vol. I: classical criticism. Cambridge: Cambridge University Press, 1989, p. 78-91.

KIRK, G. S. The Iliad: a commentary. Volume II: books 5-8. Editor geral G. Kirk. Cambridge: Cambridge University Press, 1990. 
LEFEBVRE, D. Capacité, force et puissance. Sur la genèse et les sens de la notion aristotélicienne de dynamis. Tese de doutorado em Filosofia. Paris: Université de Paris I, 2000.

MUGLER, C. Les origines de la science grecque chez Homère. L'homme et l'univers physique. Paris: Klincksieck, 1963.

NILSSON. Geschichte der griechischen Religion. I. Band: die Religion Griechenlands bis auf die griechische Weltherrschaft. Munique: C. H. Beck'sche, 1955 ( $3^{\mathrm{a}}$ ed., 1967).

OLENDER, M. Les langues du paradis. Aryens et Sémites: un couple providentiel. Paris: Gallimard / Le Seuil, 1989.

ONIANS, R. B. The origins of european thought. About the body, the mind, the soul, the world, time and fate. Cambridge: Cambridge University Press, 1951 (2 ${ }^{\mathrm{a}} \mathrm{ed}$. 1954).

PRÉ-SOCRÁTICOS. Pré-socráticos. Fragmentos, doxografia, comentários. Volume I. Coleção "Os pensadores". Trad. e org. de J. C. de Souza. São Paulo: Nova Cultural, 1989.

POUPARD, P., org. Dictionnaire des Religions. Paris: Presses Universitaires de France, 1984, vol. 1, 1984 (3a ed. 1993).

RICHARDSON, N. Homeric professors in the age of the sophists. Proceedings of the Cambridge Philological Society, 201 (new series 21), 1975, p. 65-81

RICHARDSON, N. The Iliad: a commentary. Volume VI: books XXI-XXIV. Cambridge: Cambridge University Press, 1993.

RUDHART, J. Considérations sur le polythéisme. Revue de Théologie et de Philosophie, 16, 1966, p. 353-364.

ROUSSEAU, P. L'intrigue de Zeus. Europe, 865, 2001, p. 120-158.

ROCCA-SERRA, G. Naissance de l'exégèse allégorique et naissance de la raison. In: MATTÉI, J. F., org. La naissance de la raison en Grèce. Actes du Congrès de Nice (mai, 1987). Paris: Presses Universitaires de France, 1990, p. 77-82.

SNELL, B. Der Weg zum Denken und zur Wahrheit. Studien zur frühgriechischen Sprache. Hypomnemata. Untersuchungen zur Antike und zu ihrem Nachleben, 57. Göttingen: Vandenhoeck \& Ruprecht, 1978.

SNELL, B. A descoberta do espirito. Trad. por A. Mourão. Lisboa: Edições 70, 1992.

VEGETTI, M. Culpability, responsibility, cause: philosophy, historiography, and medicine in the fifth century. In: LONG, A. A., org., The Cambridge companion to early greek philosophy. Cambridge: Cambridge University Press, 1999, p. 271-289.

VERNANT, J.-P. Aspects de la personne dans la religion grecque. In: VERNANT, J.-P. Mythe et pensée chez les Grecs. Etudes de psychologie historique. Paris: Maspéro, 1965 (2 $2^{a}$ ed. Éditions de la Découverte, 1990), p. 267-282.

VLASTOS, G. Theology and philosophy in early Greek thought. In: Studies in Greek philosophy. Volume I: the presocratics. Edited by D. W. Graham. Princeton (New Jersey): Princeton University Press, 1993, p. 24-25. 